\title{
Immunomodulatory effects of Pseudostellaria heterophylla (Miquel) Pax on regulation of Th1/Th2 levels in mice with atopic dermatitis
}

\author{
YOU YEON CHOI ${ }^{1}$, MI HYE KIM ${ }^{1}$, KWANG SEOK AHN ${ }^{2}$, JAE-YOUNG UM $^{3}$, \\ SEOK-GEUN LEE ${ }^{4}$ and WOONG MO YANG ${ }^{1}$ \\ Departments of ${ }^{1}$ Convergence Korean Medical Science, ${ }^{2}$ Korean Pathology and \\ ${ }^{3}$ Korean Pharmacology; ${ }^{4}$ Cancer Preventive Material Development Research Center, \\ College of Korean Medicine, Kyung Hee University, Seoul 02447, Republic of Korea
}

Received November 24, 2015; Accepted November 17, 2016

DOI: $10.3892 / \mathrm{mmr} .2016 .6093$

\begin{abstract}
Pseudostellaria heterophylla (PH) has various pharmacological effects that include immunologic enhancement and anti-oxidation. However, it remains unclear whether $\mathrm{PH}$ exerts beneficial effects in dermatological diseases. The present study examined the effects of $\mathrm{PH}$ on a 2,4-dinitrochlorobenzene (DNCB)-induced atopic dermatitis (AD) mouse model and elucidated its underlying mechanism of action. PH extract (1 and $100 \mathrm{mg} / \mathrm{ml}$ ) was applied topically to DNCB-treated dorsal skin of mice every day for 11 days. The immunomodulatory effects of PH were evaluated by measuring skin thickness, mast cell infiltration, serum levels of immunoglobulin E (IgE), and mRNA expression levels of $\mathrm{T}$ helper (h)1/Th2 and pro-inflammatory cytokines in dorsal skin. In addition, cluster of differentiation (CD) $4^{+} \mathrm{T}$ cells were detected in dorsal skin by immunohistochemistry. Topical application of PH significantly reduced the thickness of dermis, epidermis and serum IgE production compared with the DNCB group. PH treatment inhibited infiltration of inflammatory cells, including mast cells and $\mathrm{CD} 4^{+} \mathrm{T}$ cells, and suppressed the mRNA expression levels of cytokines (interferon- $\gamma$, interleukin- $4,-6,-8$ and $-1 \beta$, and tumor necrosis factor- $\alpha$ ) associated with the immune response. Furthermore, PH treatment significantly downregulated the protein expression levels of nuclear factor- $\kappa \mathrm{B}$, phosphorylated inhibitor of $\kappa \mathrm{B} \alpha$ and mitogen-activated protein kinases. The results suggested that $\mathrm{PH}$ may be a potential therapeutic
\end{abstract}

Correspondence to: Professor Woong Mo Yang, Department of Convergence Korean Medical Science, College of Korean Medicine, Kyung Hee University, 1 Hoegi-dong, Dongdaemun-gu, Seoul 02447, Republic of Korea

E-mail: wmyang@khu.ac.kr

Key words: Pseudostellaria heterophylla, atopic dermatitis, $\mathrm{T}$ helper 1/T helper 2 cytokine strategy for the treatment of AD via the modulation of Th1 and Th2 levels.

\section{Introduction}

Atopic dermatitis (AD) involves a complex immune response mediated by Thelper (Th) 1 and Th2 T cell subsets (1). Chronic skin lesions of AD are dominated by Th1-type cytokine responses with high levels of interferon (IFN)- $\gamma$. The Th2-type cytokines, interleukin (IL)-4, -6 and -13, serve important roles in the increase in the levels of serum immunoglobulin $\mathrm{E}(\mathrm{IgE})$ and mast cells during AD development (2). Therefore, Th1 and Th2 cytokines may contribute to AD lesions (3).

The topical application of steroids is typically recommended for the treatment of AD (4). However, topical steroids have various well-known adverse effects, including skin atrophy, a tendency for bruising, tachyphylaxis and the rebound phenomenon (5). Therefore, herbal medicines have been investigated as potential topical agents for the treatment of AD.

Pseudostellaria heterophylla (Miquel) Pax has been described as a type of 'qi-enriching and tonic drug' (6), which has a beneficial effect for the immune system (7). In addition, Pseudostellaria heterophylla (PH) has mild toning effects on the body, leading to its widespread use in herbal medicines and healthcare products $(8,9)$. The primary components of $\mathrm{PH}$ include polysaccharides, cycle peptides, amino acids, volatile compounds, saponins, amino acids and minerals. In particular, macromolecule polysaccharides are considered to be the primary active component of PH (10). Previous studies have suggested that $\mathrm{PH}$ has immunomodulatory, anti-inflammatory and anti-oxidant properties $(7,11)$. These diverse biological activities may be beneficial for the treatment of AD.

The present study therefore aimed to evaluate the immunomodulatory activity of $\mathrm{PH}$ water extracts in a 2,4-dinitrochlorobenzene (DNCB)-induced mouse model of AD.

\section{Materials and methods}

Preparation of sample. PH was supplied by Jung-do Herb Inc. (Guri, Korea) and was authenticated by 
Professor Woong Mo Yang (Kyung Hee University, Seoul, Korea). The crude drug (100 g) was extracted with $1,000 \mathrm{ml}$ distilled water for $24 \mathrm{~h}$ at room temperature. Following filtration, the extracted solution was concentrated in a rotary evaporator, freeze-dried for three days, and stored in aliquots at $-70^{\circ} \mathrm{C}$. The yield from the dried roots was $23.09 \%$. The authenticated voucher specimens (no. PH131201) were stored in the College of Pharmacy of Kyung Hee University. The PH extracts was dissolved in distilled water immediately prior to use.

Animal model. A total of 25 female BALB/c mice (age, 6 weeks; weight, 18-22 g) were obtained from Raon Bio Inc. (Yongin, Korea) and housed in an air-conditioned room at a temperature of $23 \pm 1^{\circ} \mathrm{C}$ and relative humidity of $60 \pm 5 \%$, under a 12-h light/dark cycle. During the experimental period, all mice received standard mouse chow and water ad libitum. All experiments were conducted according to the guidelines of the Guide for the Care and Use of Laboratory Animals of the National Institutes of Health. The protocol was approved by Committee on Care and Use of Laboratory Animals of the Kyung Hee University (approval no. KHUASP (SE)-14-030; Seoul, Korea). Following an acclimation period of 1 week, mice were randomly divided into five groups $(n=5)$ : NOR, in which mice were challenged with vehicle treatment as a baseline control; DNCB, in which mice were sensitized with $100 \mu \mathrm{l} /$ day 1 or $0.5 \%$ DNCB (Sigma-Aldrich; Merck Millipore, Darmstadt, Germany) as negative control; DEX, in which mice were topically treated with $100 \mu \mathrm{l} /$ day $10 \mu \mathrm{M}$ dexamethasone (DEX; Sigma-Aldrich; Merck Millipore) following DNCB sensitization as positive control; $\mathrm{PH} 1$, in which mice were topically treated with $100 \mu \mathrm{l} /$ day $1 \mathrm{mg} / \mathrm{ml} \mathrm{PH}$ following DNCB sensitization; and $\mathrm{PH} 100$, in which mice were topically treated with $100 \mu \mathrm{l} /$ day $100 \mathrm{mg} / \mathrm{ml} \mathrm{PH}$ following DNCB sensitization.

To induce dermatitis, $100 \mu 11 \%$ DNCB solution [in acetone: olive oil at a ratio of 4:1 (v/v)] was applied onto the shaved dorsal skin of all mice excluding the NOR group once a day for 3 days (day 1-3). Following the first challenge, mice were left untreated for 4 days (day 4-7). In the second challenge, $\mathrm{PH}$ (1 or $100 \mathrm{mg} / \mathrm{ml}$ ) or DEX was topically applied to mice prior to the application of $0.5 \%$ DNCB for 11 consecutive days (day 8 to day 18). An equal volume of vehicle was applied to the NOR group at the same time points. All animals were sacrificed $24 \mathrm{~h}$ after the last treatment (day 19) under anesthesia with intraperitoneal injection of a tiletamine/zolazepam mixture (30 mg/kg, Zoletil 50; Virbac Lab, Carros, France). Serum was collected by cardiac puncture and the dorsal skin of mice was biopsied for histopathology and measurement of tissue cytokines levels.

Histopathology. To evaluate skin thickening and mast cell infiltration, the dorsal skin samples $\left(1 \mathrm{x} 0.4 \mathrm{~cm}^{2}\right)$ were prepared at sacrifice (day 19). Samples were fixed in $10 \%$ buffered formalin (Sigma-Aldrich; Merck Millipore), embedded in paraffin and cut into $4-\mu \mathrm{m}$ thick sections. Following dewaxing and dehydration of paraffin sections, hematoxylin and eosin staining was performed to assess skin thickening and toluidine blue staining to detect mast cells as previously described (12). Histopathological alterations were examined using the Leica Application Suite (LAS; Leica Microsystems, Inc., Buffalo
Grove, IL, USA) and viewed at magnification, x100. Skin thickness was measured in $>5$ fields, at intervals of $200 \mu \mathrm{m}$, in each sample $(n=5)$. The number of mast cells was measured in the entire area of each section $(19.05 \times 25.4 \mathrm{~cm})$ for each sample $(n=5)$.

IgE concentrations in plasma, as detected by ELISA. Blood was allowed to clot for $30 \mathrm{~min}$ at room temperature. The serum was prepared by centrifugation $(10,000 \mathrm{x}$ g for $10 \mathrm{~min}$ at room temperature) and stored at $-70^{\circ} \mathrm{C}$ until use. The concentrations of $\operatorname{IgE}$ in serum were determined using a Mouse IgE ELISA kit (cat. no. 555248; BD Biosciences, Franklin Lakes, NJ, USA) according to the manufacturer's protocol.

Cluster of differentiation (CD) $4^{+}$cell expression, as detected by immunohistochemistry (IHC). IHC was performed according to the manufacturer's protocol. To retrieve antigens in the skin tissues, the deparaffinized sections were boiled in $10 \mathrm{mM}$ sodium citrate buffer for $30 \mathrm{~min}$. Endogenous peroxidase was subsequently blocked by incubation in $3 \%$ $\mathrm{H}_{2} \mathrm{O}_{2}$ for 30 min and slides were blocked with $5 \%$ normal goat serum (Santa Cruz Biotechnology, Inc., Dallas, TX, USA) in phosphate-buffered saline (PBS) containing 5\% fetal bovine serum (Corning, Inc., Corning, NY, USA), $2 \%$ bovine serum albumin (BSA; Vector Laboratories, Burlingame, CA, USA) and $0.1 \%$ Triton $\mathrm{X}-100$ for $1 \mathrm{~h}$. Following washing in PBS three times, the sections were incubated overnight with an antibody against biotin anti-mouse CD4 (cat. no. 100403; BioLegend, Inc., San Diego, CA, USA), diluted 1:100 in normal goat serum, in a humidified chamber. After washing with PBS, the biotinylated goat anti-mouse IgG (cat. no. BA-9200; diluted 1:200 in TBST; Vector Laboratories) was applied for $2 \mathrm{~h}$ at room temperature. The slides were subsequently incubated with an Avidin/Biotinylated Enzyme Complex kit (Vector Laboratories) for $1 \mathrm{~h}$, followed by the substrate chromogen (3,3-diaminobenzidine; Dako, Glostrup, Denmark), and counterstained by hematoxylin staining. CD4 staining was visualized using LAS (magnification, x200).

RNA isolation and reverse transcription-polymerase chain reaction $(R T-P C R)$. To detect $\mathrm{mRNA}$ expression levels of various inflammatory cytokines, RT-PCR was performed. Total RNA was extracted from excised dorsal skin using TRIzol ${ }^{\circledR}$ reagent (Invitrogen; Thermo Fisher Scientific, Inc., Waltham, MA, USA) according to the manufacturer's protocol, and quantified by determining the optical density at a wavelength of $260 \mathrm{~nm}$. Isolated total RNA (1 $\mu \mathrm{g})$ was used as a template for cDNA synthesis. RT was performed using a cDNA Synthesis kit (Invitrogen) at $45^{\circ} \mathrm{C}$ for $1 \mathrm{~h}$. The reaction was terminated by incubation at $95^{\circ} \mathrm{C}$ for $5 \mathrm{~min}$, and cDNA was stored at $-20^{\circ} \mathrm{C}$. PCR was performed using the synthesized cDNA as a template and Maxime PCR premix kit (Invitrogen; Thermo Fisher Scientific, Inc.) and specific primers for mouse IFN- $\gamma$, IL-4, IL-6, IL-8, tumor necrosis factor (TNF)- $\alpha$, IL-1 $\beta$ and GAPDH. Cycling conditions were as follows: Initial denaturation cycle for $5 \mathrm{~min}$ at $94^{\circ} \mathrm{C}, 30$ cycles of amplification for $2 \mathrm{~min}$ at $72^{\circ} \mathrm{C}, 1 \mathrm{~min}$ at $94^{\circ} \mathrm{C}, 1 \mathrm{~min}$ at $60^{\circ} \mathrm{C}$, and a final extension phase consisting of 1 cycle of $10 \mathrm{~min}$ at $72^{\circ} \mathrm{C}$. The primers were designed using Primer Express software version 3.0 (Applied Biosystems; Thermo Fisher Scientific, Inc.) and the 
Table I. Primer sequences used for reverse transcription polymerase chain reaction.

\begin{tabular}{|c|c|c|c|}
\hline Target gene & Direction & Sequence $\left(5^{\prime}-3^{\prime}\right)$ & $\begin{array}{l}\text { Amplicon } \\
\text { size (bp) }\end{array}$ \\
\hline Interferon- $\gamma$ & $\begin{array}{l}\text { Forward } \\
\text { Reverse }\end{array}$ & $\begin{array}{l}\text { AGCGGCTGACTGAACTCAGATTGTAG } \\
\text { GTCACAGTTTTCAGCTGTATAGGG }\end{array}$ & 330 \\
\hline Interleukin-4 & $\begin{array}{l}\text { Forward } \\
\text { Reverse }\end{array}$ & $\begin{array}{l}\text { ATGGGTCTCAACCCCCAGC } \\
\text { GCTCTTTACGCTTTCCAGGAAGTC }\end{array}$ & 300 \\
\hline Interleukin-6 & $\begin{array}{l}\text { Forward } \\
\text { Reverse }\end{array}$ & $\begin{array}{l}\text { ATCAACTCCTTCTCCACA AGCGC } \\
\text { GAAGAGCCCTCAGGCTGGACTG }\end{array}$ & 628 \\
\hline Interleukin-8 & $\begin{array}{l}\text { Forward } \\
\text { Reverse }\end{array}$ & $\begin{array}{l}\text { TGTGGGAGGCTGTGTTTGTA } \\
\text { ACGAGACCAGGAGAAACAGG }\end{array}$ & 200 \\
\hline Tumor necrosis factor- $\alpha$ & $\begin{array}{l}\text { Forward } \\
\text { Reverse }\end{array}$ & $\begin{array}{l}\text { GGTGCAATGCAGAGCCTTCC } \\
\text { CAGTGATGTAGCGACAGCCTGG }\end{array}$ & 173 \\
\hline Interleukin-1 $\beta$ & $\begin{array}{l}\text { Forward } \\
\text { Reverse }\end{array}$ & $\begin{array}{l}\text { CTCTAGACCATGCTACAGAC } \\
\text { TGGAATCCAGGGGAAACACTG }\end{array}$ & 291 \\
\hline GAPDH & $\begin{array}{l}\text { Forward } \\
\text { Reverse }\end{array}$ & $\begin{array}{l}\text { GGCATGGACTGTGGTCATGA } \\
\text { TTCACCACCATGGAGAAGGC }\end{array}$ & 376 \\
\hline
\end{tabular}

sequences of primers are presented in Table I. Amplicons were visualized on $2 \%$ agarose gel stained with ethidium bromide using a GDS-200D Gel Image System version PSRem164 (UVP, Inc., CA, USA). All mRNA levels were normalized to the housekeeping gene GAPDH by a computerized densitometry system (ImageJ version 1.38e; National Institutes of Health, Bethesda, MD, USA).

Analysis of inflammatory protein expression by western blot analysis. To determine the mechanisms underlying the development of AD-like skin lesions, the protein expression levels of the pro-inflammatory mediators, such as nuclear factor (NF)- $\kappa \mathrm{B}$, phosphorylated (p)-inhibitor of (I) $\kappa \mathrm{B} \alpha$ and p-mitogen-activated protein kinases (MAPKs) were examined in skin homogenates. To detect $\mathrm{p}-\mathrm{I} \kappa \mathrm{B} \alpha$ the dorsal skin samples were homogenized by the addition of the cytoplasmic buffer [10 mM 4-(2-hydroxyethyl)-1-piperazineethanesulfonic acid (HEPES) at pH 7.9, $10 \mathrm{mM} \mathrm{KCl,} 0.1 \mathrm{mM}$ EDTA, $0.1 \mathrm{mM}$ ethylene glycol-bis ( $\beta$-aminoethyl ether)-N,N,N',N'-tetraacetic acid (EGTA), $1 \mathrm{mM}$ dithiothreitol (DTT), $0.15 \%$ Nonidet $\mathrm{P}-40,50 \mathrm{mM} \beta$-glycerophosphate, $10 \mathrm{mM} \mathrm{NaF}$ and $5 \mathrm{mM}$ $\left.\mathrm{Na}_{3} \mathrm{VO}_{4}\right]$ containing protease inhibitors. The cytoplasmic protein extracts were collected following sample centrifugation at $10,000 \times \mathrm{g}$ for $30 \mathrm{~min}$ at $4^{\circ} \mathrm{C}$. Cytoplasmic proteins were collected from the supernatant, and nuclear lysis buffer (20 mM HEPES at pH 7.9, $400 \mathrm{mM} \mathrm{NaCl,} 1 \mathrm{mM}$ EDTA, $1 \mathrm{mM}$ EGTA, $1 \mathrm{mM}$ DTT, 0.50\% Nonidet P-40, $50 \mathrm{mM}$ $\beta$-glycerophosphate, $10 \mathrm{mM} \mathrm{NaF}$ and $5 \mathrm{mM} \mathrm{Na}_{3} \mathrm{VO}_{4}$ ) was added to the pellet, homogenized on ice for $20 \mathrm{~min}$, and centrifuged at $16,000 \times \mathrm{g}$ for $30 \mathrm{~min}$ at $4^{\circ} \mathrm{C}$. The resultant homogenate was carefully removed without disturbing the pellet for assay of activated $\mathrm{NF}-\kappa \mathrm{B}$. The protein expression levels of the MAPKs extracellular signal-regulated kinase (ERK) 1/2, c-Jun N-terminal kinase (JNK) and p38 were confirmed in whole extracts using radioimmunoprecipitation assay buffer containing a protease inhibitor cocktail. The cytoplasmic, nuclear and whole protein extracts were subsequently used for western blotting. Proteins were quantified by the bicinchoninic acid method according to the manufacturer's protocol (Pierce; Thermo Fisher Scientific, Inc.). The proteins $(30 \mu \mathrm{g})$ were resolved in $10 \%$ SDS-PAGE gels and electroblotted onto polyvinylidene difluoride membranes. The membranes were blocked with $5 \%$ BSA for $1 \mathrm{~h}$ at room temperature and incubated with antibodies against $\beta$-actin (cat. no. sc-47778; Santa Cruz Biotechnology, Inc.), lamin-B (cat. no. sc-374015; Santa Cruz Biotechnology, Inc.), NF-кB (cat. no. sc-372; Santa Cruz Biotechnology, Inc.), p-IкB $\alpha$ (cat. no. sc-8404; Santa Cruz Biotechnology, Inc.), ERK1/2 (cat. no. 4695; Cell Signaling Technology, Inc., Danvers, MA, USA), p-ERK1/2 (cat. no. 4370; Cell Signaling, Inc.), JNK (cat. no. 9252; Cell Signaling Technology, Inc.), p-JNK (cat. no. 9251; Cell Signaling Technology, Inc.), p38 (cat. no. 9212; Cell Signaling Technology, Inc.) and p-p38 (cat. no. 4631; Cell Signaling Technology, Inc.), diluted 1:1,000 in TBS containing Tween-20 (TBST) for overnight at $4^{\circ} \mathrm{C}$. Membranes were subsequently incubated with a horseradish peroxidase-conjugated secondary anti-mouse antibody (cat. no. sc-2005; Santa Cruz Biotechnology, Inc.) and anti-rabbit antibody (cat. no. sc-2004; Santa Cruz Biotechnology, Inc.) diluted 1:2,000 in TBST for $2 \mathrm{~h}$ at room temperature. The immunoreactive proteins were detected with an Enhanced Chemiluminescence reagent (Pierce; Thermo Fisher Scientific, Inc.). Band intensities were quantified by a computerized densitometry software Image J version $1.38 \mathrm{e}$.

Statistical analysis. Data are expressed as the mean \pm standard deviation. Comparisons between the values for different variables were analyzed by one-way analysis of variance followed by Dunnett's t-test. $\mathrm{P}<0.05$ was considered to indicate a statistically significant difference using a GraphPad PRISM 5 software version 5 (GraphPad Software, Inc., La Jolla, CA, USA). 
A

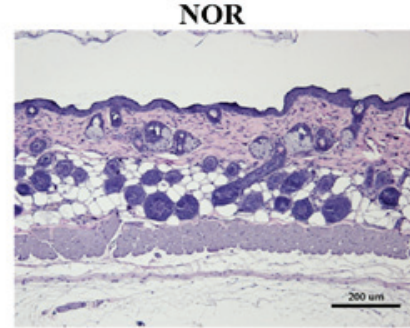

DEX

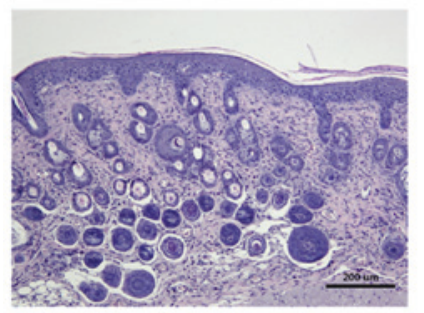

B

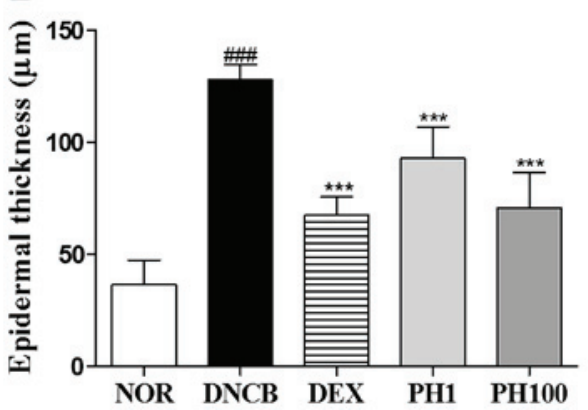

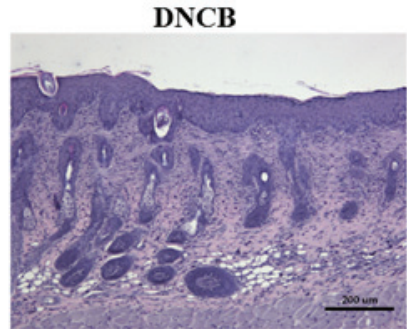

PH1

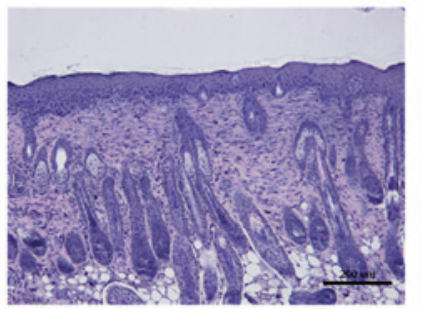

C

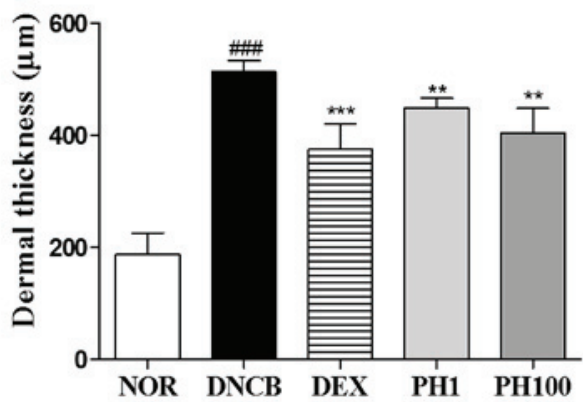

Figure 1. Pseudostellaria heterophylla treatment reduces dorsal skin thickness. (A) Histological assessment of the dorsal skin of each group following hematoxylin and eosin staining. Magnification, $x 100$; scale bar $=200 \mu \mathrm{m}$. (B) Epidermal and (C) dermal thicknesses were quantified in 35 randomly selected fields per group. Data are presented as the mean \pm standard deviation $(\mathrm{n}=5)$. ${ }^{\# \# \#} \mathrm{P}<0.001$ vs. NOR; ${ }^{* * *} \mathrm{P}<0.001$ and ${ }^{* *} \mathrm{P}<0.01$ vs. DNCB. NOR, vehicle-treated mice; DNCB, 2,4-dinitrochlorobenzene-treated mice; DEX, 2,4-dinitrochlorobenzene- and dexamethasone-treated mice; PH1, 2,4-dinitrochlorobenzene- and $1 \mathrm{mg} / \mathrm{ml}$ Pseudostellaria heterophylla-treated mice; PH100, 2,4-dinitrochlorobenzene- and $100 \mathrm{mg} / \mathrm{ml}$ P. heterophylla-treated mice.

\section{Results}

PH treatment reduces dorsal skin thickness. To evaluate AD symptoms, histological analysis was performed on the dorsal skin of each group (Fig. 1A). Repeated DNCB-treatment caused a thickening of the epidermis and dermis $(\mathrm{P}<0.001)$. Topically applied 1 and $100 \mathrm{mg} / \mathrm{ml} \mathrm{PH}$ suppressed epidermal hyperplasia and dermal thickening, as did $10 \mu \mathrm{M}$ DEX. Quantitative analysis revealed that the PH1, PH100 and DEX groups $(\mathrm{P}<0.001)$ demonstrated a $27.4,44.6$ and $47.2 \%$ reduction in epidermal thickness (Fig. 1B). In addition, 12.3, 27.0 and $27.1 \%$ reduction of dermal thickness was observed in $\mathrm{PH} 1$ $(\mathrm{P}<0.01)$, PH100 $(\mathrm{P}<0.01)$ and DEX $(\mathrm{P}<0.001$; Fig. 1C).

PH inhibits the infiltration of mast cells into the dermis. DNCB-treated skin lesions $(\mathrm{P}<0.001)$ revealed increased infiltration of mast cells compared with the NOR group (Fig. 2A and B). Topical application of PH1, PH100 or DEX markedly decreased this infiltration $(\mathrm{P}<0.001)$.

$P H$ reduces serum IgE levels. The concentration of $\operatorname{IgE}$ in the plasma of the NOR group was $143.4 \pm 51.49 \mathrm{ng} / \mathrm{ml}$. This increased to $4348.0 \pm 446.05 \mathrm{ng} / \mathrm{ml}$ in the DNCB group ( $\mathrm{P}<0.001$; Fig. 2C). The serum IgE levels in the PH1, PH100 and DEX groups was reduced $\sim 1.4-, \sim 3.7$ - and $\sim 2.2$-fold compared with the DNCB group $(\mathrm{P}<0.001)$.
PH suppresses the infiltration of $\mathrm{CD}^{+}$cells. To examine the accumulation of $\mathrm{CD}^{+}$cells in allergic inflamed skin, the expression of CD4 in dorsal skin sections was detected by IHC (Fig. 3). Increased immunostaining was observed in the DNCB group compared with the NOR group. The detection of CD4 expression was markedly reduced in mice treated with PH1, PH100 or DEX compared with the DNCB group.

PH inhibits the mRNA expression levels of Th1 and Th2 cytokines in dorsal skin lesions. To elucidate the effect of $\mathrm{PH}$ treatment on cytokine expression, alterations in the mRNA expression levels of various cytokines were analyzed, including Th1-specific (IFN- $\gamma$ ), Th2-specific (IL-4) and pro-inflammatory (IL-6, IL-8, TNF- $\alpha$ and IL-1 $\beta$ ) cytokines (Fig. 4). The DNCB group $(\mathrm{P}<0.001)$ expressed increased expression levels of Th1 and pro-inflammatory cytokine mRNA in skin tissues compared with the NOR group. PH (1 and $100 \mathrm{mg} / \mathrm{ml})$ and DEX suppressed the Th1 and pro-inflammatory cytokine production stimulated by DNCB application. The inhibitory effects of the PH1, PH100 and DEX groups were as follows: $32.5,51.0$ and $47.7 \%$ for IFN- $\gamma$ (PH1 and PH100; $\mathrm{P}<0.001) ; 26.8,36.2$ and $27.5 \%$ for TNF- $\alpha$ (PH1, $\mathrm{P}<0.01$; PH100, $\mathrm{P}<0.001$ ); and 14.7, 29.8 and $44.2 \%$ for IL-1 $\beta$ (PH100, P<0.001), respectively. Similarly, the mRNA expression levels of IL-4, IL-6 and IL-8 markedly increased following DNCB application compared with the NOR group 
A

NOR

DNCB

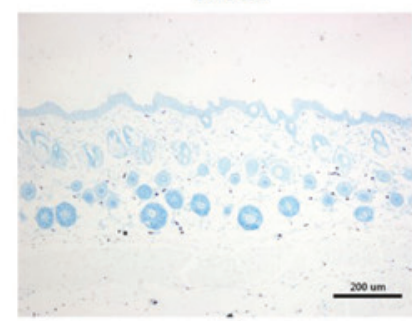

DEX
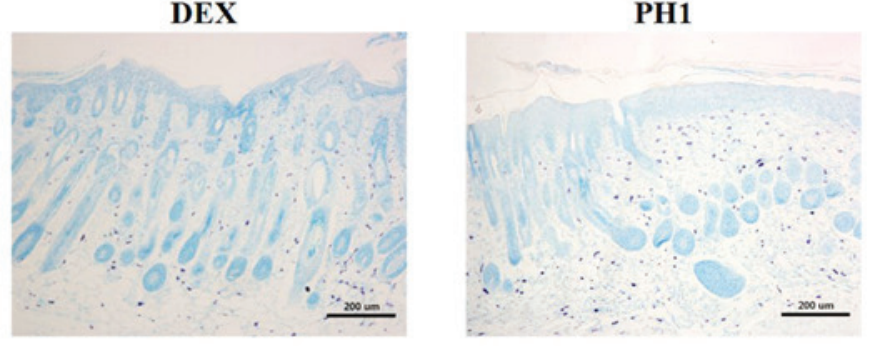

PH100

B

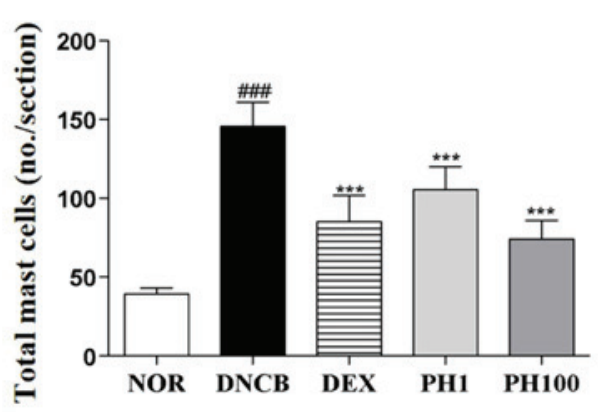

C

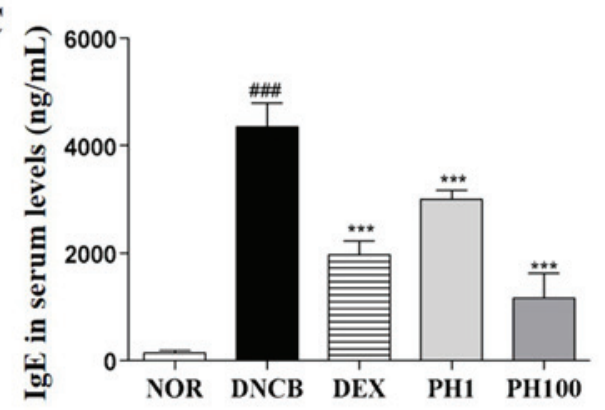

Figure 2. Pseudostellaria heterophylla decreases the number of mast cells in dorsal skin and serum IgE levels. (A) Mast cells were detected by toluidine blue staining. Magnification, x100; scale bar=200 $\mu \mathrm{m}$. (B) Infiltration of mast cells was quantified by counting the mast cells in the slides (n=5). (C) Serum levels of IgE were measured by ELISA. Data are presented as the mean \pm standard deviation $(n=5)$. ${ }^{\# \# \#} \mathrm{P}<0.001$ vs. NOR; ${ }^{* * *} \mathrm{P}<0.001$ and ${ }^{* *} \mathrm{P}<0.01$ vs. DNCB. NOR, vehicle-treated mice; DNCB, 2,4-dinitrochlorobenzene-treated mice; DEX, 2,4-dinitrochlorobenzene- and dexamethasone-treated mice; PH1, 2,4-dinitrochlorobenzene- and $1 \mathrm{mg} / \mathrm{ml}$ Pseudostellaria heterophylla-treated mice; PH100, 2,4-dinitrochlorobenzene- and $100 \mathrm{mg} / \mathrm{ml}$ P. heterophylla-treated mice; $\mathrm{IgE}$, immunoglobulin E.

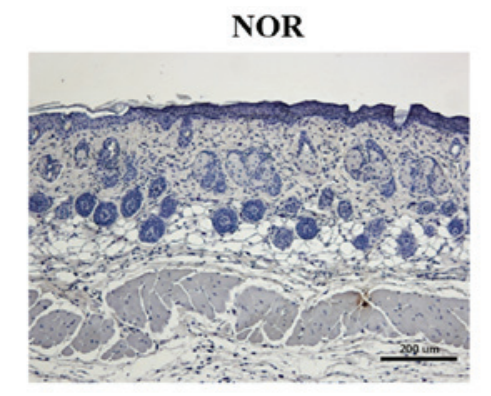

DEX

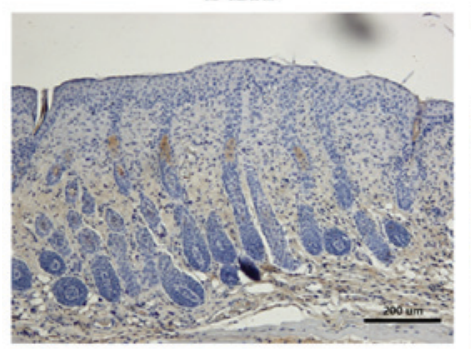

DNCB

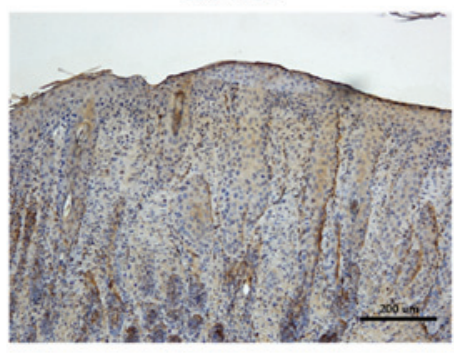

PH1

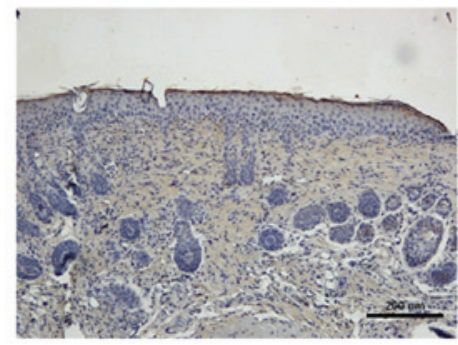

PH100

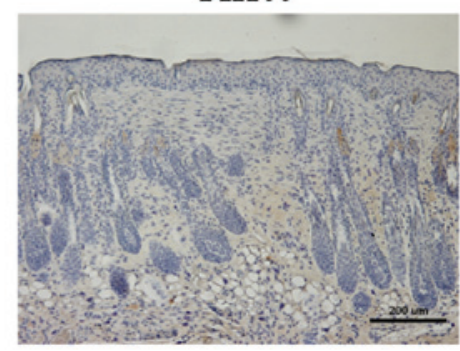

Figure 3. Pseudostellaria heterophylla suppresses the infiltration of $\mathrm{CD} 4^{+} \mathrm{T}$ cells into dorsal skin. Representative images revealing CD4 staining, as detected by immunohistochemistry. Magnification, x100; scale bar=200 $\mu \mathrm{m}$. NOR, vehicle-treated mice; DNCB, 2,4-dinitrochlorobenzene-treated mice; DEX, 2,4-dinitrochlorobenzene- and dexamethasone-treated mice; PH1, 2,4-dinitrochlorobenzene- and $1 \mathrm{mg} / \mathrm{ml}$ Pseudostellaria heterophylla-treated mice; PH100, 2,4-dinitrochlorobenzene- and $100 \mathrm{mg} / \mathrm{ml}$ P. heterophylla-treated mice; $\mathrm{CD}$, cluster of differentiation. 
$\mathbf{A}$

\begin{tabular}{|c|c|}
\hline IFN- $\gamma$ & 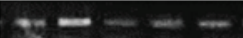 \\
\hline IL-4 & 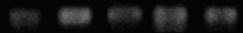 \\
\hline IL-6 & $-m-m$ \\
\hline IL-8 & 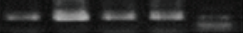 \\
\hline TNF- $\alpha$ & $m-n=m$ \\
\hline IL-1 $\beta$ & 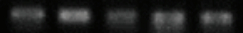 \\
\hline GAPDH & - \\
\hline
\end{tabular}

B
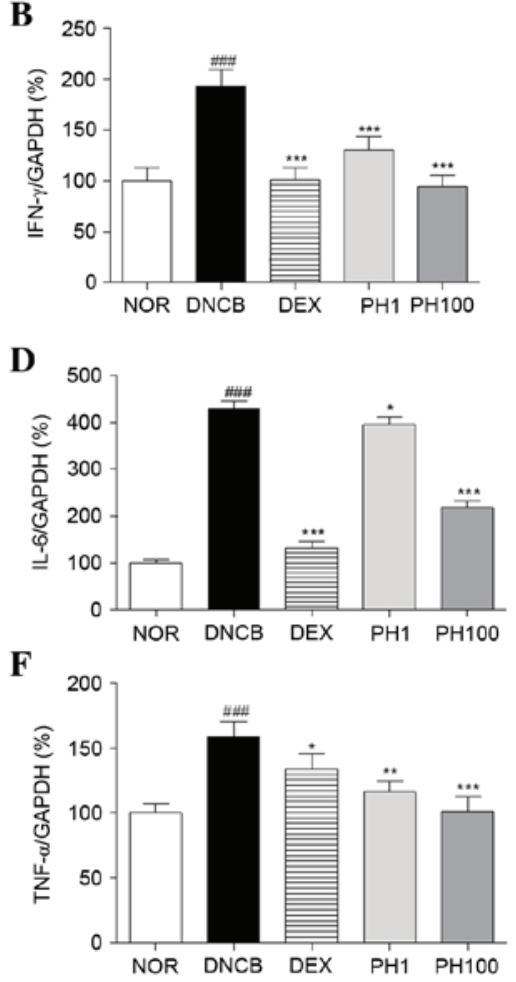

C

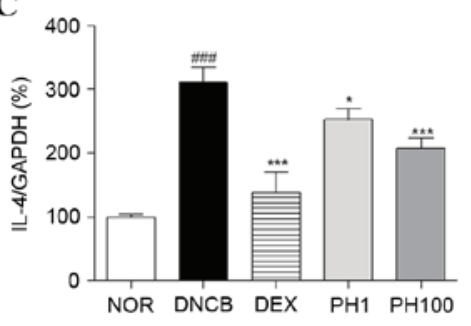

$\mathbf{E}$
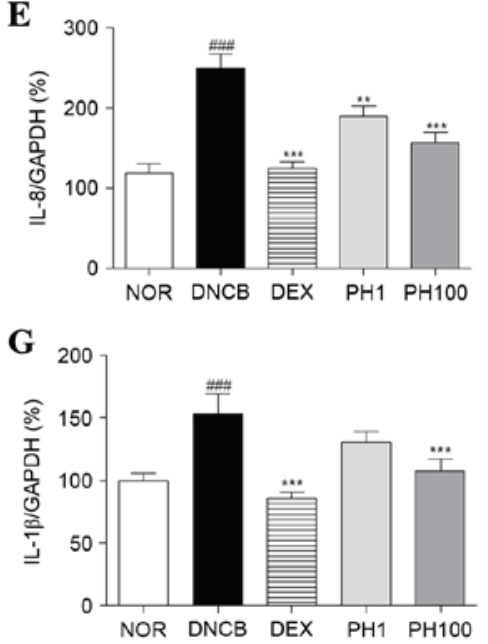

Figure 4. Pseudostellaria heterophylla inhibits the mRNA expression levels of Th1, Th2 and pro-inflammatory cytokines in dorsal skin. (A) The expression of mRNA was quantified using reverse transcription-polymerase chain reaction. (B) IFN- $\gamma$, (C) IL-4, (D) IL-6, (E) IL-8, (F) TNF- $\alpha$ and (G) IL-1 $\beta$ mRNA expression levels were normalized to GAPDH. Data are presented as the mean \pm standard deviation $(\mathrm{n}=5)$. ${ }^{\# \#} \mathrm{P}<0.001$ vs. NOR; ${ }^{* * *} \mathrm{P}<0.001,{ }^{* *} \mathrm{P}<0.01$ and ${ }^{*} \mathrm{P}<0.05$ vs. DNCB. NOR, vehicle-treated mice; DNCB, 2,4-dinitrochlorobenzene-treated mice; DEX, 2,4-dinitrochlorobenzene- and dexamethasone-treated mice; PH1, 2,4-dinitrochlorobenzene- and $1 \mathrm{mg} / \mathrm{ml}$ Pseudostellaria heterophylla-treated mice; PH100, 2,4-dinitrochlorobenzene- and 100 mg/ml P. heterophylla-treated mice; Th, T helper; IFN, interferon; IL, interleukin; TNF, tumor necrosis factor.

$(\mathrm{P}<0.001)$. PH treatment suppressed IL-4 and IL-6 mRNA expressions at all concentrations $(\mathrm{PH} 1, \mathrm{P}<0.05 ; \mathrm{PH} 100$, $\mathrm{P}<0.001)$. In $\mathrm{PH}$-treated AD legion, elevated IL-8 mRNA levels were decreased $(\mathrm{PH} 1, \mathrm{P}<0.01 ; \mathrm{PH} 100, \mathrm{P}<0.001)$. In addition, DEX treatment significantly reduced the expression levels of these cytokines $(\mathrm{P}<0.001)$.

PH decreases the protein expression levels of $N F-\kappa B, p-I \kappa B \alpha$ and MAPKs in dorsal skin lesions. The expression of inflammatory cytokines is regulated by the transcription factor p65 $\mathrm{NF}-\kappa \mathrm{B}$. PH treatment (1 and $100 \mathrm{mg} / \mathrm{ml})$ inhibited the nuclear translocation of p65 NF- $\kappa \mathrm{B}$ about 34.4 and $56.0 \%$, respectively $(\mathrm{P}<0.001)$. DEX group showed $50.4 \%$ reduction of $\mathrm{NF}-\kappa \mathrm{B}$ protein expression $(\mathrm{P}<0.001)$. Also, $\mathrm{p}-\mathrm{I} \kappa \mathrm{B} \alpha$ expressions in $\mathrm{PH} 1$ $(\mathrm{P}<0.05), \mathrm{PH} 100(\mathrm{P}<0.001)$ and $\mathrm{DEX}(\mathrm{P}<0.001)$ groups were significantly decreased (Fig. 5A). Similarly, the protein expression levels of p-ERK1/2 ( $\mathrm{P}<0.001$, Fig. 5B), p-p38 $(\mathrm{P}<0.01$, Fig. 5C) and p-JNK ( $<<0.001$, Fig. 5D) were dose-dependently downregulated following $\mathrm{PH}$ treatment.

\section{Discussion}

The present study demonstrated an immunomodulatory effect of $\mathrm{PH}$ against $\mathrm{AD}$ progression and elucidated the underlying mechanism of action. The morphology of the DNCB-induced AD model revealed increased epidermal thickening and dermal infiltration of $\mathrm{CD}^{+}{ }^{+} \mathrm{T}$ cells and mast cells, consistent with AD skin lesions. Repeated treatment with PH effectively improved the symptoms of AD by reducing hyperkeratosis and hyperplasia in the epidermis and dermis.

The high levels of IgE measured in AD are associated with the activation of underlying inflammatory cascades (13). In addition, mast cells exhibit immunomodulatory activity via cross-talk with various biological mediators involved in IgE-mediated AD $(14,15)$. Therefore, the present study investigated whether topical treatment of $\mathrm{PH}$ affected the serum level of IgE and the infiltration of mast cells. The DNCB group expressed the greatest levels of $\operatorname{IgE}$ in serum and numbers of mast cells in skin. Topical application of 1 and $100 \mathrm{mg} / \mathrm{ml} \mathrm{PH}$ suppressed serum IgE levels by 30.9 and $73.2 \%$, respectively. The reduction of $\mathrm{IgE}$ concentrations is consistent with the suppression of mast cell infiltration into the dermis following $\mathrm{PH}$ treatment.

$\mathrm{T}$ cells are crucial for immune responses, and the dysregulation of the $\mathrm{CD}^{+} \mathrm{T}$ cell subset is an important aspect of $\mathrm{AD}$ pathophysiology (16). A previous study determined that $\mathrm{CD}^{+}$ $\mathrm{T}$ cells increased in numbers in the AD-like skin lesions in DNCB-induced mice model (17). Accordingly, the elevation of CD4 expression in the dermis may suggest that Th1 and Th2 cells are involved (4). The present study revealed that $\mathrm{PH}$ suppressed increases in $\mathrm{CD}^{+}$cell numbers, were assumed to be $\mathrm{CD}^{+} \mathrm{T}$ cells in the skin. Activated $\mathrm{CD} 4^{+} \mathrm{T}$ cells have two distinct subfamilies, Th1 cells and Th2 cells, classified by the cytokines they secrete. The topical treatment of PH significantly suppressed the expression levels of Th1-(IFN- $\gamma$ ) and Th2-(IL-4 and -6) specific cytokines. In addition, IFN- $\gamma$ may 
A
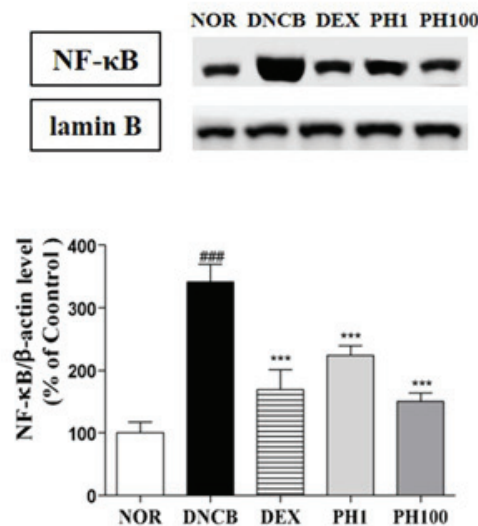

NOR DNCB DEX PH1 PH100
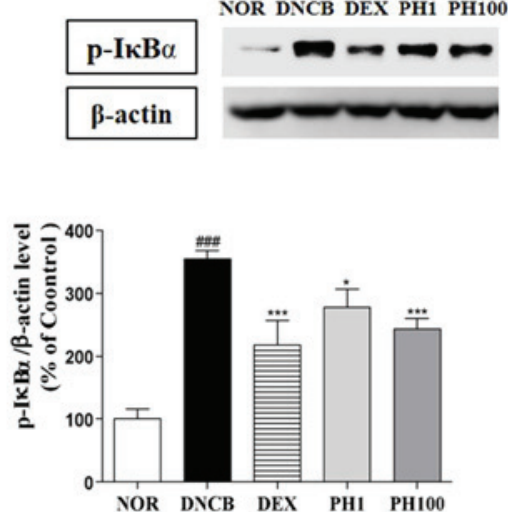

B
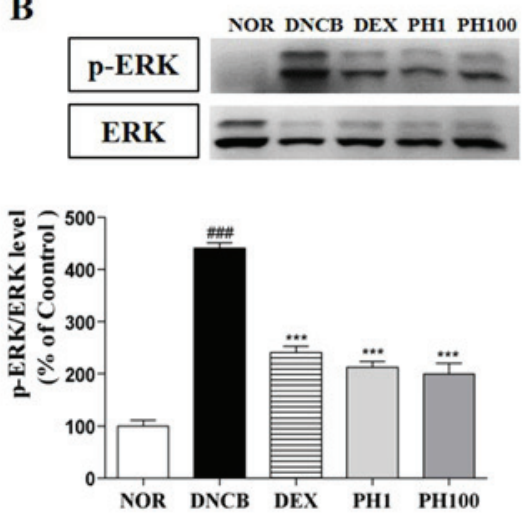

C
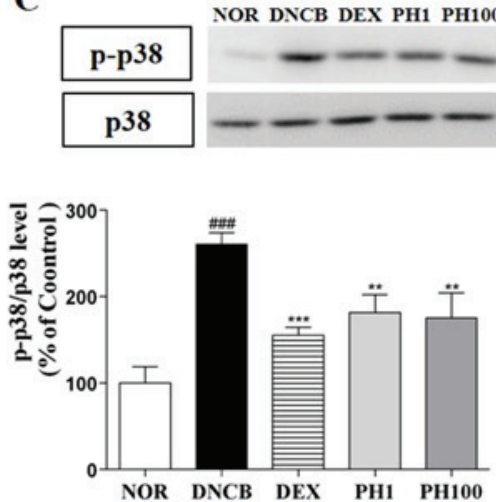

D
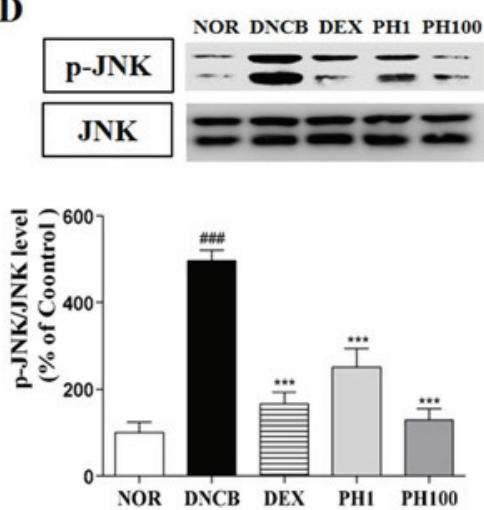

Figure 5. Pseudostellaria heterophylla decreases the protein expression levels of NF- $\kappa \mathrm{B}, \mathrm{p}-\mathrm{I} \kappa \mathrm{B} \alpha$ and MAPKs in dorsal skin lesions. (A) NF- $\mathrm{B}$ protein expression levels in nuclear extracts and $\mathrm{p}-\mathrm{I} \kappa \mathrm{B} \alpha$ protein expression levels in cytosolic extracts. The protein expression levels of the MAPKs (B) p-ERK1/2, $(\mathrm{C}) \mathrm{p}-\mathrm{p} 38$ and (D) p-JNK were analyzed in whole extracts. Data are presented as the mean \pm standard deviation $(\mathrm{n}=5)$. ${ }^{\# \# \#} \mathrm{P}<0.001 \mathrm{vs}$. NOR; ${ }^{* * *} \mathrm{P}<0.001,{ }^{* * *} \mathrm{P}<0.01$ and ${ }^{*} \mathrm{P}<0.05$ vs. DNCB. NOR, vehicle-treated mice; DNCB, 2,4-dinitrochlorobenzene-treated mice; DEX, 2,4-dinitrochlorobenzene- and dexamethasone-treated mice; PH1, 2,4-dinitrochlorobenzene- and $1 \mathrm{mg} / \mathrm{ml}$ Pseudostellaria heterophylla-treated mice; PH100, 2,4-dinitrochlorobenzene- and 100 mg/ml P. heterophylla-treated mice; NF, nuclear factor; I, inhibitor; p, phosphorylated; MAPK, mitogen-activated protein kinase; ERK, extracellular signal-regulated kinase; JNK, c-Jun N-terminal kinase.

contribute to the proliferation and differentiation of infiltrating macrophages, which may aggravate AD-like skin lesions (18). The reduction of IFN- $\gamma$ expression levels may be associated with the immunosuppressive effects of $\mathrm{PH}$, via inhibition of macrophage recruitment to the site of inflammation. Th2 cells produce IL-4 and -6 , and are associated with cell and membrane destruction in acute atopic dermatitis $(19,20)$. $\mathrm{PH}$ treatment decreased the increased expression levels of IL-4 and -6 induced by DNCB application.

The modulating effect of $\mathrm{PH}$ on Th1 and Th2 immune responses appears to have been demonstrated by the effects on serum IgE levels. In addition, overexpression of IL-8, TNF- $\alpha$ and IL-1 $\beta$ may be associated with a high number of infiltrated macrophages and basophils in the dermis (21). Topical treatment with PH significantly reduced IL- 8 , TNF- $\alpha$ and IL- $1 \beta$ expression levels and these findings were more pronounced in the PH100 group.

$\mathrm{NF}-\kappa \mathrm{B}$ is critical for inflammatory cytokine transcriptional regulation and is important for immune responses. The activation of the $\mathrm{NF}-\kappa \mathrm{B}$ signaling pathway results in the phosphorylation and therefore degradation of I $\mathrm{B}$ (22). In the DNCB-induced mouse model of the present study, $\mathrm{PH}$ inhibited the phosphorylation of $\mathrm{I} \kappa \mathrm{B} \alpha$ and the nuclear translocation of NF- $\kappa$ B. In addition, MAPKs represent a critical signaling cascade in immune responses, interacting with $\mathrm{NF}-\kappa \mathrm{B}$ to regulate inflammation $(23,24)$. In the present study, DNCB-induced phosphorylation of all three MAPKs was reduced by PH treatment. These results support the hypothesis that the inhibitory effects of PH on pro-inflammatory cytokine expression are due to suppression of the MAPK and NF- $\kappa \mathrm{B}$ signaling pathways.

In conclusion, the results of the present study demonstrated a reduction in the pathological features of $\mathrm{AD}$, including dorsal skin thickness, mast cell infiltration and release of $\mathrm{IgE}$ following treatment with $\mathrm{PH}$, supporting the clinical potential of $\mathrm{PH}$ as an alternative therapeutic strategy for the management of AD. The inhibition of Th1 and Th2 inflammatory cytokines suggests that $\mathrm{PH}$ may exert anti-AD activity by regulating a series of immune pathological events, including the expression of NF- $\kappa \mathrm{B}, \mathrm{p}-\mathrm{I} \kappa \mathrm{B} \alpha$ and MAPKs. PH may therefore affect Th1/Th2 immune dysregulation, leading to the suppression of the features of AD.

\section{Acknowledgements}

The present study was supported by the National Research Foundation of Korea funded by the Korean government (grant no. NRF-2015R1A4A1042399). 


\section{References}

1. Levy ML: Atopic dermatitis: Understanding the disease and its management. Curr Med Res Opin 23: 3091-3103, 2007.

2. Minnicozzi M, Sawyer RT and Fenton MJ: Innate immunity in allergic disease. Immunol Rev 242: 106-127, 2011.

3. Mosmann TR and Coffman RL: Th1 and th 2 cells: Different patterns of lymphokine secretion lead to different functional properties. Annu Rev Immunol 7: 145-173, 1989.

4. Leung DY, Boguniewicz M, Howell MD, Nomura I and Hamid QA: New insights into atopic dermatitis. J Clin Invest 113: 651-657, 2004

5. Nakamura K: Pathogenesis and treatment of allergic skin disease-atopic dermatitis. Arerugi 64: 703-706,2015 (In Japanese)

6. Liu J, Pei M, Zheng C, Li Y, Wang Y, Lu A and Yang L: A systems-pharmacology analysis of herbal medicines used in health improvement treatment: Predicting potential new drugs and targets. Evid Based Complement Alternat Med 2013: 938764, 2013.

7. Ng TB, Liu F and Wang HX: The antioxidant effects of aqueous and organic extracts of panax quinquefolium, panax notoginseng, codonopsis pilosula, pseudostellaria heterophylla and glehnia littoralis. J Ethnopharmacol 93: 285-288, 2004.

8. Pang W, Lin S, Dai Q, Zhang H and Hu J: Antitussive activity of pseudostellaria heterophylla (miq.) pax extracts and improvement in lung function via adjustment of multi-cytokine levels. Molecules 16: 3360-3370, 2011.

9. Li X, Chen Y, Lai Y, Yang Q, Hu H and Wang Y: Sustainable utilization of traditional chinese medicine resources: Systematic evaluation on different production modes. Evid Based Complement Alternat Med 2015: 218901, 2015.

10. Li Y and Yang XW: Studies on chemical constituents of root tuber of cultivated pseudostellaria heterophylla (Zheshen No. 1). Zhongguo Zhong Yao Za Zhi 33: 2353-2355, 2008 (In Chinese).

11. Wong CK, Leung KN, Fung MC, Fung KP and Choy YM: The induction of cytokine gene expression in murine peritoneal macrophages by pseudostellaria heterophylla. Immunopharmacol Immunotoxicol 16: 347-357, 1994.

12. Choi YY, Kim MH, Hong J, Kim K and Yang WM: Effect of Dangguibohyul-Tang, a mixed extract of astragalus membranaceus and angelica sinensis, on allergic and inflammatory skin reaction compared with single extracts of astragalus membranaceus or angelica sinensis. Evid Based Complement Alternat Med 2016: 5936354, 2016.

13. Shin HS, See HJ, Jung SY, Choi DW, Kwon DA, Bae MJ, Sung KS and Shon DH: Turmeric (curcuma longa) attenuates food allergy symptoms by regulating type $1 /$ type 2 helper $t$ cells (th1/th2) balance in a mouse model of food allergy. J Ethnopharmacol 175: 21-29, 2015.
14. Kang H, Lee CH, Kim JR, Kwon JY, Seo SG, Han JG, Kim BG, Kim JE and Lee KW: Chlorella vulgaris attenuates dermatophagoides farinae-induced atopic dermatitis-like symptoms in nc/nga mice. Int J Mol Sci 16: 21021-21034, 2015.

15. Park S, Kim da S, Kang S and Shin BK: Synergistic topical application of salt-processed phellodendron amurense and sanguisorba officinalis linne alleviates atopic dermatitis symptoms by reducing levels of immunoglobulin e and pro-inflammatory cytokines in nc/nga mice. Mol Med Rep 12: 7657-7664, 2015.

16. Vocanson M, Hennino A, Chavagnac C, Saint-Mezard P, Dubois B, Kaiserlian D and Nicolas JF: Contribution of cd4(+) and cd8(+) T-cells in contact hypersensitivity and allergic contact dermatitis. Expert Rev Clin Immunol 1: 75-86, 2005.

17. Zhang EY, Chen AY and Zhu BT: Mechanism of dinitrochlorobenzene-induced dermatitis in mice: Role of specific antibodies in pathogenesis. PLoS One 4: e7703, 2009.

18. Lee HS, Kim SK, Han JB, Choi HM, Park JH, Kim EC, Choi MS, An HJ, Um JY, Kim HM and Min BI: Inhibitory effects of Rumex japonicus Houtt. On the development of atopic dermatitis-like skin lesions in Nc/Nga mice. Br J Dermatol 155: 33-38, 2006.

19. Chen L, Martinez O, Overbergh L, Mathieu C, Prabhakar BS and Chan LS: Early up-regulation of Th2 cytokines and late surge of Th1 cytokines in an atopic dermatitis model. Clin Exp Immunol 138: 375-387, 2004.

20. Lee HJ, Lee HP, Ha SJ, Byun DG and Kim JW: Spontaneous expression of mrna for iL-10, GM-CSF, TGF-beta, TGF-alpha, and IL-6 in peripheral blood mononuclear cells from atopic dermatitis. Ann Allergy Asthma Immunol 84: 553-558, 2000

21. Szegedi K, Lutter R, Res PC, Bos JD, Luiten RM, Kezic S and Middelkamp-Hup MA: Cytokine profiles in interstitial fluid from chronic atopic dermatitis skin. J Eur Acad Dermatol Venereol 29: 2136-2144, 2015

22. Li W, Zhao Y, Xu X, Ma W, Gao P, Wang Y, Liang K and Li R: Rebamipide suppresses TNF- $\alpha$ mediated inflammation in vitro and attenuates the severity of dermatitis in mice. FEBS J 282: 2317-2326, 2015.

23. Lee J, Choi YY, Kim MH, Han JM, Lee JE, Kim EH, Hong J, Kim J and Yang WM: Topical application of angelica sinensis improves pruritus and skin inflammation in mice with atopic dermatitis-like symptoms. J Med Food 19: 98-105, 2016.

24. Mishra S, Tripathi A, Chaudhari BP, Dwivedi PD, Pandey HP and Das M: Deoxynivalenol induced mouse skin cell proliferation and inflammation via MAPK pathway. Toxicol Appl Pharmacol 279: 186-197, 2014. 